\title{
All different, all equal: evidence of a heterogeneous Neolithic population at the Bom Santo Cave necropolis (Portugal)
}

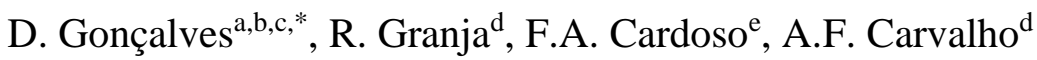

${ }^{a}$ Research Centre for Anthropology and Health (CIAS), Department of Life Sciences, University of Coimbra, Calçada Martim de Freitas, Coimbra 3000-456, Portugal.

${ }^{\mathrm{b}}$ Centre for Functional Ecology, Department of Life Sciences, University of Coimbra, Calçada Martim de Freitas, 3000-456 Coimbra, Portugal.

'Laboratório de Arqueociências, Direcção Geral do Património Cultural and LARC/CIBIO/InBIO, Rua da Bica do Marquês 2, 1300-087 Lisboa, Portugal ${ }^{\mathrm{d} U n i v e r s i d a d e ~ d o ~ A l g a r v e, ~ C a m p u s ~ d e ~ G a m b e l a s, ~ 8000-117 ~ F a r o, ~ P o r t u g a l . ~}$ ${ }^{e}$ Centro em Rede de Investigação em Antropologia (CRIA), FCSH, Universidade NOVA de Lisboa, Av. Berna, 26-C, 1069-061 Lisboa, Portugal.

Received 20 February 2015, accepted 2 December 2015

*Corresponding author. Tel.: +351 963501561. E-mail address:

davidmiguelgoncalves@gmail.com (David Gonçalves) 


\begin{abstract}
The objective of this paper was to contribute to the discussion regarding the sociopolitical organization of south-western Iberian Middle Neolithic populations. To that end, the preservation and distribution of human remains and the dispersion of grave goods within two rooms of the Bom Santo Cave (Rooms A and B) were investigated and combined with genetic and isotopic data previously published. Grave goods distribution and skeletal analyses highlighted an important diversity in terms of funerary practices thus corroborating data from ancient DNA and $\mathrm{Sr} / \mathrm{O}$ isotopic analyses that suggested a great genetic and geographic diversity. Grave goods presented an uneven spatial distribution and were made of raw materials from different sources and using different pottery manufacturing styles albeit typologically homogeneous. The preservation and distribution of human remains suggested that Room A was mainly used for secondary depositions while Room B was used for both primary and secondary depositions. No link between the two rooms was found since remains from the same individuals were apparently exclusive of one room or another. The results suggest that this society presented substantial inner genetic, social and geographical heterogeneity. Most probably, this was due to the presence of distinct but coeval groups in the cave that shared a larger-scale social identity (as in "segmentary societies") or, less likely, to the presence of one single, but internally heterogeneous society (as in fully sedentary societies) that assimilated foreigners.
\end{abstract}

\title{
Introduction
}

\section{The archaeological site}

Bom Santo is a Neolithic burial cave located in the eastern slope of the Montejunto Mountain, ca. $50 \mathrm{~km}$ north of Lisbon, in the Estremadura province of central Portugal (Fig. 1). The province's landscape is composed of extensive limestone massifs, in which dozens of caves have been discovered and excavated since the mid-19th century. However, with the exception of some caves studied at the onset of archaeological studies in Portugal, such as Furninha (Delgado, 1884), most of the 20th century was characterized by a remarkable decline regarding the quality of the field record. It was only in its last quarter that excavations with good stratigraphic controls and detailed recording of particular contexts were put into practice (e.g., Leitão et al., 1987; Vilaça and Cunha-Ribeiro, 1987; Oosterbeek and Cruz 1991; Zilhão, 1984, 1992) which has 
provided a sound scientific basis allowing further analyses to be carried out. This is clearly the case of the Bom Santo Cave.

The cave was untouched since its last funerary use and was discovered during a speleological survey in 1993. The cave entrance had been deliberately closed with a limestone boulder, most probably during the Neolithic, a practice commonly acknowledged in megalithic monuments and understood as "condemnation structures". The nineteen radiocarbon determinations on human bones indicated a relatively short period of occupation, between 3800 and 3400 cal BCE, within the Middle Neolithic (Table 1). Upon its discovery, Bom Santo was immediately recognized as a vast cemetery complex composed of several galleries and corridors. As a research strategy, these were formally subdivided into 11 distinct sectors, totalling $285 \mathrm{~m}^{2}$. A provisional minimum number of 121 individuals was estimated to be lying on the surface of the cave (Duarte, 1998) and countless more skeletons deposited beneath. Archaeological excavations were only undertaken in two of eleven sectors, named Rooms A and B. Overall, these rooms revealed a significant quantity of highly homogeneous material culture items along with the absence of multi-stratified archaeological deposits. It should be noted that rooms A and B probably formed a single room at the start of the human occupation of the cave. The division of this space was created by a stone block that collapsed sometime during the 400 years of the cave funerary use (Fig. 1). Both spaces (designated separately as rooms A and B for practical purposes only) continued to be used after that event. This is supported by the presence of a clear path, with no bones on its surface, which is contiguous to the part of the stone block facing Room B. It should also be stated that Room A is not yet fully excavated. Therefore, the results presented here do not refer to its whole section.

Contrasting with the very homogenous profile of the material culture, which is typical of the Middle Neolithic in central and southern Portugal, the ancient DNA (aDNA) analysis showed a significant genetic diversity in a Bom Santo sample (Table 1). Nine of the 14 tested individuals had different mitochondrial haplotypes and haplogroups (Fernández and Arroyo-Pardo, 2014). In addition, oxygen and strontium isotopic analyses were indicative of high indices of human mobility. Indeed, while the local fauna (two red deer and one sheep/goat samples) had 0.7099-0.7102 range of values (average of $0.7098 \pm 0.0003$ ), humans exhibited 0.7103-0.7136 (average of $0.7117 \pm 0.001)$. When plotted in a bar graph, it was possible to classify eleven out of 
the abovementioned 14 individuals as being "non-local or at least mobile for a considerable part of the year, obtaining foods from areas with higher local ${ }^{87} \mathrm{Sr} /{ }^{86} \mathrm{Sr}$ values" (Price, 2014: 156). Stable carbon and nitrogen isotopes revealed terrestrialoriented subsistence practices but with variable percentages of aquatic (i.e., freshwater) food sources in diets, spanning from 6-7\% to $39-42 \%$, with an average of $23 \%$ (Carvalho and Petchey, 2013; Petchey, 2014). Overall, both trends suggested that the territory of the Bom Santo population comprised the Middle Holocene lower Tagus estuary (the probable origin of such freshwater foods), up to the Maior river basin (from where one pottery vessel was brought to the cave as a grave good; Carvalho and Masucci, 2014), and the neighbouring plains of central Alentejo along the Sorraia Valley (for a comprehensive description of the reasoning leading to this interpretation, see Carvalho et al., 2015).

These results raised the question of how homogeneous was the population using the cave at a cultural level, namely in both its funerary practices and material cultures. This is an important question and would contribute to improve our understanding about the social and political structure of Middle Neolithic societies in south-western Iberia.

\section{INSERT Fig. 1 AND Table 1 ABOUT HERE}

\section{Aim of the present paper}

The present paper attempts to determine whether or not the funerary practice observed in two rooms of the Bom Santo Cave - Room A and Room B (Fig. 1) - was actually the result of a single or two distinct but co-existing funerary practices. Human remains and artefact assemblages were examined to provide an independent model to shed light on the population heterogeneity hypothesis that was raised after finding genetic and isotopic heterogeneity in the Bom Santo sample (Carvalho et al., 2015). Emphasis was therefore placed on material culture and human remains aiming to scrutinize patterns of funerary practices since we assumed that different practices reflected population cultural heterogeneity.

Some of the human remains found in Bom Santo presented partial anatomical connections, i.e. first-rate links, as defined by Duday and Guillon (2006). This indicated that some surface depositions were originally part of a primary burial. This pattern of deposition was clearly present in Room B where considerable portions of two 
individualized skeletons were still in situ (Fig. 2). In Room A, the few remains found in apparent anatomical connection referred to bones known to have persistent joints such as the hip, elbow, knee or ankle. Therefore, they cannot be used to make a clear distinction between a primary and a secondary deposition (Granja et al., 2014a) because bones in such apparent anatomical position may be present in both types of deposition. As a result, they either represented primary depositions or, alternatively, body parts brought together to Room A from the location where primary burials took place. Conversely, evidence of secondary depositions was unmistakable since some arrangements of specific bones - such as crania - were present in both Rooms A and B (Granja et al., 2014a). However, for the vast majority of the human remains, no clear funerary practice could be immediately recognized in the field. An archaeothanatological approach (Duday, 2005, 2006; Duday et al., 2009) was then applied in an attempt to reconstruct the chaîne opératoire that led to the funerary settings found in rooms A and B of the Bom Santo Cave.

\section{INSERT Fig. 2 ABOUT HERE}

\section{Material and methods}

The human skeletal remains recovered from Rooms A and B of the Bom Santo Cave comprise 7465 bone fragments and 2039 tooth fragments. The room provenance was properly recorded for most of these elements during the excavation (for a comprehensive inventory, see Granja et al., 2014b).

First, a taphonomic analysis was carried out in order to better understand the processes affecting bone completeness and to assess if any difference observed in the remains found in each room could be related to differential funerary practices in terms of the type of deposition (primary or secondary). Completeness was used as the exclusive indicator of bone and tooth preservation in this analysis although other indicators could have been used (Bello et al., 2006). As a result, the completeness of each skeletal element was recorded. For this purpose, we adapted the coding recommendations from Buikstra and Ubelaker (1994) because these do not completely allow for the discrimination between elements with either less or more than $50 \%$ completeness. Therefore, elements more than $75 \%$ complete were coded as 1 ; elements 
between $50 \%$ and $75 \%$ complete were coded as 2; elements between $25 \%$ and $50 \%$ were coded as 3; and the elements less than $25 \%$ complete were coded as 4 . Inter-room differential preservation was assessed by using Mann-Whitney's statistical tests to compare the completeness of specific skeletal elements.

Afterwards, an archaeothanatological examination of the human remains was carried out. The frequency of bones associated with labile joints, such as the ones from hands and feet was calculated; the same was carried out for the long bones. This task was undertaken since the presence, or absence, of bones associated with labile joints, such as the distal phalanges or some of the vertebrae (Bello and Andrews, 2006), have been frequently used to assign skeletal remains to primary or secondary burials (Roksandic, 2002; Duday, 2006).

Furthermore, an attempt was made to match bones from each individual that were not in anatomical connection but rather dispersed throughout the two rooms. To do this, second rate links were investigated (Duday and Guillon, 2006). This process takes into consideration similarities between joint anatomy, age at death, pathological changes, and pairing in the linkage procedure (Duday and Guillon, 2006). All this information needs to be contextualized with field data. Fortunately, the Bom Santo excavation was thoroughly performed and detailed field excavation data were available. Within this methodological framework, articular contiguity of some selected joints was inspected. The joints selected were the atlanto-occipital, atlanto-axial, temporo-mandibular, sacroiliac, acetabulo-femoral, and talo-calcaneal. Other joints were not selected because in our opinion, contiguity was more difficult and less reliable to assess. In addition, a search for paired bones located in the two different rooms was conducted.

Finally, grave goods were taken into consideration. The provenience of raw materials is indicative of mobility indices or exchange networks. Some raw materials may be geographically specific, and their transport from one location to another may be interpreted as the result of trade, exchange and mobility. Therefore, they may be used both to pinpoint the geographical origin of groups or individuals and to assess their interactions. The first analysis of the provenience of certain grave goods of Bom Santo was already published, namely that of personal adornments (Dean and Carvalho, 2014), pottery vessels (Carvalho and Masucci, 2014) and polished stone tools (Cardoso, 2014). However, the present study added another dimension: the grave goods spatial scattering 
patterns within the excavated rooms. This was examined and used to explore their possible association with differentiated funerary practices.

\section{Results}

The completeness of skeletal elements in Bom Santo was quite reasonable. Several agents responsible for bone and tooth fragmentation and modification were identified (Granja et al., 2014a). For example, evidence of rodent and carnivore activity was detected, as well as calcium carbonated concretion and manganese oxide staining. However, the most altering or destructive taphonomic agent was apparently trampling or crushing. This was probably due to the 400 years of continuous use of the cave. A statistically significant difference between Room A and Room B was found regarding the completeness of some of the skeletal remains (Table 2) - teeth, hands, feet and all long bones. However, this significant difference was somewhat misleading. From those, only long bones presented medium to large ( $r=.243$ to $r=.370$, in the case of the humeri, femora and tibiae) or even large ( $r>.371$ in the case of the radii, ulnae and fibulae) effect sizes. The effect sizes for the clavicle $(r=.208)$, teeth $(r=.154)$ and hand bones $(\mathrm{r}=.116)$ were very small. Therefore, the magnitude of the difference between the completeness of the latter skeletal elements from both rooms was not as evident. As for the bones known to have labile joints, the comparison between rooms $\mathrm{A}$ and $\mathrm{B}$ provided an interesting result. A minimum number of 36 individuals in Room B and 35 individuals in Room A has been estimated based on the repetition of lower right first molar - tooth 46, according to the codification system of the Fédération Dentaire International (Granja et al., 2014b). However, Figures 3 and 4 show that the frequency of hand distal phalanges $(\mathrm{HPh})$ and foot distal phalanges $(\mathrm{FPh})$ was quite contrasting, showing a large number in Room $\mathrm{B}(\mathrm{HPh} \mathrm{n}=153 ; \mathrm{FPh} \mathrm{n}=81)$ and a much smaller number in Room A ( $\mathrm{HPh} \mathrm{n}=19 ; \mathrm{FPh} \mathrm{n}=25)$. For example, the right first distal hand phalanx was represented by 17 elements in Room B, and 3 elements in Room A, thus representing $47.2 \%$ and $8.6 \%$ of the estimated minimum number of individuals (MNI) of each room, respectively. This pattern was also found for the first distal foot phalanx, although to a lesser extent: $28.6 \%(n=10)$ for Room B and $11.4 \%(n=4)$ for Room A. In both cases, the frequency was clearly smaller for Room A than for Room B even though both had a similar estimate of the MNI based on tooth 46 . This greater number 
of elements in Room B when compared to Room A was also observed for the most labile elements of the vertebral column and hand bones (Granja et al. 2014a). The ratio of elements present in Room A in relation to elements present in Room B was very unbalanced: 1:4.2 for the vertebrae and 1:4.7 for the hand bones.

\section{INSERT Fig. 3, Fig. 4 AND Table 2 About HERE}

Interestingly, the frequencies of most long bones known to have persistent joints provided quite different results. For the upper limbs, the Room A/Room B ratios were 1:0.8 for clavicles, 1:1.1 for humeri, 1:1.9 for radii and 1:1.6 for ulnae. For the lower limbs, the ratios were 1:1.5 for femora, $1: 1.5$ for tibiae and 1:1.2 for fibulae. These values demonstrated that such bones were not missing as much from Room A as in the case of the smaller bones associated with labile joints. In the case of the clavicle, its frequency in Room A was actually greater than in Room B.

The attempt of matching bones located in different rooms through articular contiguity was unsuccessful. The attempt of matching antimeres revealed several paired bones within the same room (e.g. seven pairs of tali in Room B and two pairs of tali in Room A); however, not a single pair, with corresponding bones located in different rooms, was unquestionably identified.

The grave good assemblages from Rooms A and B were mostly composed of knapped (flint blades and microliths from presently unknown sources) and polished (axes and adzes made of metamorphic rocks) tools with 41 and 21 artefacts, respectively. Bone tools (mainly awls or points) were found in smaller numbers $(n=21)$. Also, personal adornments were found, namely beads, pendants and bracelets made of shell $(n=70)$ or stone $(n=9)$. As for ceramics, only two complete pots were found. These were associated with a small number of loose sherds $(n=11$, two of them rimsherds).

Differences in grave goods between Rooms A and B were investigated by comparing the distribution of the adornments, pottery and polished stone tools in each excavation unit (Fig. 5). The analysis showed an uneven distribution of grave goods, with the large majority of the adornments and potsherds being found in Room A. This pattern was present regardless of the raw material and the geographical area of provenience. Adornments, in particular, showed a notable concentration in B4 and immediate 
squares, which Dean and Carvalho (2014) interpreted as being elements of, at least, a single composite necklace, made with materials from different sources (shell and schist beads). The exceptions were the polished stone tools, which were evenly scattered in both rooms and thus testifying to a completely different behaviour.

\section{INSERT Fig. 5 ABOUT HERE}

\section{Discussion}

We tested the hypothesis of the two rooms, A and B, having distinct funerary uses and associated burial practices. Coupled with intra-site distribution of grave goods and their geographical origins, this could in theory inform us about some cultural traits of the population represented in the Bom Santo Cave. The hypothesis was tested by exploring the preservation and distribution of human remains as well as the distribution of grave good assemblages within the two excavated rooms.

Results strongly supported the possibility that those sections - or at least considerable parts of them - have been used for different funerary practices during the Middle Neolithic. Indeed, while a secondary funerary practice comprising the rearrangement of skeletal elements was identified in both Rooms A and B, the identification of primary depositions was only clearly noted for Room B. No conclusive evidence of this latter practice was found in Room A since there was no indication of skeletons, or skeletal elements, maintaining first-rate osteological links and bones known to have labile joints were very rare.

The long bones were the skeletal elements presenting a larger variation regarding its completeness and therefore were the most useful for comparison of inter-room preservation. Other skeletal elements were either generally too complete or too incomplete. Long bones from Room A were systematically more complete than long bones from Room B, a scenario compatible with the hypothesis of Room A containing secondary depositions composed of bones that were deliberately selected by virtue of their better preservation. Although Room B presented a significantly better overall completeness of skeletal elements than Room A, this result should be disregarded because Room B comprised a lot more skeletal elements that were systematically more complete (teeth, wrist, hand and foot bones; 1222 for Room A vs. 2497 for Room B). 
Although the MNI was not completely equal in both rooms, this would hardly explain the differences found for the frequencies of bones known to have labile joints from both rooms. The low frequencies found in Room A suggest that it was not recurrently used for the deposition of complete bodies. If it had been so, the expected count of labile bones would have been greater or at least comparable to the count from Room B. Also, it suggests that room separation along with funerary practice separation was quite long-lasting since the opposite, at the very least, would probably cause fewer differences in terms of the frequencies of small bones with labile joints. Apparently, only the larger bones - and better preserved ones, as seen above - would have therefore been systematically brought to this location while the smaller bones were usually left at the location where the primary deposition took place. Again, this suggests that most of the human remains in Room A were probably the result of secondary depositions.

The results also demonstrated that bones from the same skeleton were most probably not dispersed throughout the two rooms thus suggesting that no funerary association between both rooms took place-i.e. that human remains from Room B were not taken to Room A-or that paired bones were systematically brought together to the latter. We are aware that taphonomy may have biased the representativeness of bones available for matching but overall skeletal preservation was quite reasonable, and thus we suspect that its role must have been negligible. Overall, the analysis of the human remains suggests that Room A was mostly used for secondary depositions and that, consequently, these were the result of transportation of relatively complete skeletons from Room B, other parts of the cave and/or from outside the cave itself. Whatever the case, the skeletal elements that have been relocated to Room A were apparently left to decompose naturally since no evidence of intentional de-fleshing was found.

The shell adornments probably had a regional origin. All species, beads of European cowrie, tusk shell, great scallop, dog whelk and bracelets made of dog cockle shells, are commonly found in varied beach environments along the Atlantic coast of the Estremadura region (Dean and Carvalho, 2014), within a radius of around 20-30 km. However, the schist beads could only have been made with blanks obtained elsewhere. All four analysed pottery materials can be related to sediments from the Montejunto region, thus locally available raw materials, as in the case of personal adornments. If classified based only on surface treatment and formal typologies, these grave goods would appear to be uniform, but a detailed analysis showed that they have distinct 
manufacture recipes. One sample in particular showed dolerite inclusions, a fact that points to similar Middle/Late Neolithic productions documented in the Rio Maior area, ca. $30 \mathrm{~km}$ north of the cave (Carvalho and Masucci, 2014). In summary, distinct technological recipes suggest different manufacturing processes probably associated with distinct groups with their own pottery-making options but sharing the same general stylistic norms. A similar behaviour was observed for the bone industry (Dean and Carvalho, 2014). At Bom Santo and other coeval cemeteries of the Estremadura and Alentejo, bone awls and points were obtained by longitudinal splitting of long bones and subsequent polishing. However, at Escoural Cave (Araújo and Lejeune, 1995) typologically similar awls were obtained by thinning the anterior or posterior surface of long bones, and not from their separation into two equal halves- "like in the case of pottery, distinct raw materials or (as in this case) ways of making artefacts aimed, however, at the same formal (culturally determined?) end-products" (Carvalho, 2014: 220).

According to Cardoso (2014), polished stone tools were made of amphibolite (seven axes and two adzes), vulcanic-sedimentary rocks (eleven adzes) and mica-schist (one adze). This implies quite distinct and more remote geological sources. The former closest outcrops are in the north-western region of the Alentejo, whereas the vulcanicsedimentary rocks have several sources in the lower Alentejo region. Such a large area, from $30-40$ to $150 \mathrm{~km}$, respectively, suggests individual or group mobility to access such resources. In this scenario, exchange within neighbouring communities is the strongest explanatory model for the presence of the more remote resources in Bom Santo.

In summary, the configuration of the human remains from Rooms A and B was most probably the product of distinct practices rather than a single dual practice (primary followed by secondary funerary practices). Thus, evidence of intra- or inter-group differences was found in Bom Santo, revealing a heterogeneous funerary behaviour and likely a segmented frame of beliefs. The results from the grave goods analysis do not contradict the analysis based on human remains. The presence of various raw materials from different sources, alongside differences in the manufacturing of some of the grave goods (pottery, bone tools), strengthens the possibility of the Bom Santo Cave population being culturally as well as genetically and geographically heterogeneous. 
At this point, it is impossible to establish if Bom Santo was a reunion point for the deceased of several groups belonging to a larger-scale social identity (as in the case of the so-called "segmentary societies") or if it merely served one single, but internally heterogeneous community. However, the former hypothesis is favoured considering the overall evidence (human remains, aDNA, stable isotopes, raw material provenances, technological traditions) retrieved from the cave and its cultural and geographic context (Carvalho, 2014; Carvalho et al., 2014). These are key factors in understanding political organization and mobility indices. Coexistence of distinct funerary practices in cave necropoleis have been tentatively suggested for some Middle Neolithic cave necropoleis situated in Portugal, such as Lugar do Canto (Leitão et al., 1987), Ossos (Oosterbeeck, 1987, 1993; Cruz, 1997) and Barrão caves (Carvalho et al., 2003). More or less evident associations between primary and secondary skeletal assemblages were suggested for these sites, but this was the first time that systematic analyses combining intra-site distribution patterns of both human remains and grave goods with genetic and isotopic data were used to address this question.

Middle Neolithic societies in central / southern Portugal — or, at least from Bom Santo - had more complex social organizational features than usually acknowledged in the Portuguese literature. Lacking clear testimonies of a rank or other social hierarchical (i.e., vertical) system, the remaining possibility is that the groups may have been organized according to a certain degree of economic, political and even funerary autarchy, in a segmentary (i.e., horizontal) structure of social organization, as has been argued previously (Carvalho, 2014; Carvalho et al., 2015). This carries important consequences regarding our understanding of "megalithic societies", especially considering the long-debated issue of their egalitarian vs. hierarchical social structure (Renfrew, 1976; Sherratt, 1990; Jorge, 1995; Masset, 1999).

Additional investigation will require an expanded research benefiting from the exploration of data at very different spatial scales. For example, excavation of other sectors of the cave is needed to assess what was their role in terms of the spatial structure and organization of the necropolis, and to test for similar patterns as observed in Rooms A and B. Also, research cannot be merely based on an intra-site focus because the funerary pattern observed at Bom Santo may have been part of a wider and thus more intricate inter-site scale. In this particular aspect, it would be extremely important to determine whether, for instance, the coeval dolmens and smaller graves of the 
Alentejo hinterland, or other burial-caves in Estremadura, played any (similar? complementary?) role in broader dynamics of Neolithic funerary practices — such as, for example, those suggested in the "fragmentation thesis" by Chapman and Gaydarska (2007) - thus evidencing a geographically wider and more complex behaviour than we presently imagine.

\section{Acknowledgments}

This study was funded by the Portuguese Foundation for Science and Technology (FCT) in the framework of the research project Bom Santo Cave and the Neolithic societies of Portuguese Estremadura, $6^{\text {th }}$ and $4^{\text {th }}$ millennia BC (PTDC/HISARQ/098633/2008), directed by António Faustino Carvalho. This project was the outcome of previous archaeological work at the site by Cidália Duarte, whom we thank for sharing her field and laboratory data. Raquel Granja was a grantee of this project at the University of Algarve (Faro, Portugal) from 2010 to 2013. David Gonçalves and Francisca Alves Cardoso are supported by the FCT through postdoctoral research grants (SFRH/BPD/84268/2012 and SFRH/BPD/43330/2008, respectively). We would also like to thank the important contribution of the two reviewers and editors that helped improving the first draft of our paper.

\section{References}

Araújo, A.C, Lejeune, M., 1995. Gruta do Escoural: necrópole neolítica e arte rupestre paleolítica. Trabalhos de Arqueologia 8. Instituto Português do Património Arquitectónico e Arqueológico, Lisbon.

Bello, S., Andrews, P., 2006. The intrinsic pattern of preservation of human skeletons and its influence on the interpretation of funerary behaviours. In: Gowland, R., Knüsel, C. (Eds.), The Social Archaeology of Funerary Remains. Oxbow Books, Oxford, pp. 1-13.

Bello, S., Thomann, A., Signoli, M., Dutour, O., Andrews, P., 2006. Age and sex bias in the reconstruction of past population structures. Am. J. Phys. Anthropol. 129, 24-38.

Buikstra, J., Ubelaker D., 1994. Standards for Data Collection from Human Skeletal Remains: Proceedings of a Seminar at the Field Museum of Natural History. Arkansas Archaeological Survey, Report 44. Fayetteville, AR. 
Cardoso, J.L., 2014. Polished stone tools. In: Carvalho, A.F. (Ed.), Bom Santo Cave (Lisbon) and the Middle Neolithic Societies of Southern Portugal. Universidade do Algarve, Faro, pp. 185-194.

Carvalho, A.F., 2014. Bom Santo cave in context. A preliminary contribution to the study of the first megalith builders of Southern Portugal. In: Carvalho, A.F. (Ed.), Bom Santo Cave (Lisbon) and the Middle Neolithic Societies of Southern Portugal. Universidade do Algarve, Faro, pp. 209-230.

Carvalho, A.F., Alves-Cardoso, F., Gonçalves, D., Granja, R., Cardoso, J.L., Dean, R.M., Gibaja, J.F., Masucci, M.A., Arroyo-Pardo, E., Fernández-Domínguez, E., Petchey, F., Price, T.D., Mateus, J.E., Queiroz, P.F., Callapez, P., Pimenta, C., Regala, F.T., 2015. The Bom Santo Cave (Lisbon, Portugal): catchment, diet, and patterns of mobility of a Middle Neolithic population. Eur. J. Archaeol. DOI: 10.1179/1461957115Y.0000000014.

Carvalho, A.F., Antunes-Ferreira, N., Valente, M.J., 2003. A gruta-necrópole neolítica do Algar do Barrão (Monsanto, Alcanena). Revista Portuguesa de Arqueologia 6, 101-119.

Carvalho, A.F., Masucci, M.A., 2014. Pottery. In: Carvalho, A.F. (Ed.), Bom Santo Cave (Lisbon) and the Middle Neolithic Societies of Southern Portugal. Universidade do Algarve, Faro, pp. 161-172.

Carvalho, A.F., Petchey, F., 2013. Stable isotope evidence of Neolithic palaeodiets in the coastal regions of Southern Portugal. J Island Coastal Archaeol. 8, 361-383. DOI: 10.1080/15564894.2013.811447.

Chapman, J.; Gaydarska, B., 2007. Parts and Wholes. Fragmentation in Prehistoric Context. Oxbow Books, Oxford.

Cruz, A.R., 1997. Vale do Nabão: do Neolítico à Idade do Bronze, Tomar. Centro Europeu de Investigação da Pré-História do Alto Ribatejo, Arkeos, 3.

Dean, R.M., Carvalho, A.F., 2014. Faunal remains, adornments and bone tools. In: Carvalho, A.F. (Ed.), Bom Santo Cave (Lisbon) and the Middle Neolithic Societies of Southern Portugal. Universidade do Algarve, Faro, pp. 195-205.

Delgado, J.F.N., 1884. La Grotte de Furninha a Peniche. Congrès International d'Anthropologie et d'Archéologie Préhistoriques. Compte Rendu de la Neuvième Session à Lisbonne. Académie Royale des Sciences, Lisbon, pp. 17-278. 
Duarte, C., 1998. Necrópole neolítica do Algar do Bom Santo: contexto cronológico e espaço funerário. Revista Portuguesa de Arqueologia. 1, 107-118.

Duday, H., 2005. L'archéothanatologie ou l'archéologie de la mort. In: Dutour, O., Hublin, J.J., Vandermeersch, B. (Eds.), Objets et méthodes en paléoanthropologie. Éditions du CTHS, Paris, pp. 153-207.

Duday, H., 2006. L'archaéothanatalogie ou l'archaeologie de la mort. In: Gowland, R., Knüsel, C. (Eds.), Social Archaeology of Funerary Remains. Oxbow Books, Oxford, pp. 30-56.

Duday, H., Cipriani, A.M., Pearce, J., 2009. The Archaeology of the Dead: Lectures in Archaeothanatology. Oxbow Books, Oxford.

Duday, H., Guillon, M., 2006. Understanding the circumstances of decomposition when the body is skeletonized. In: Schmitt, A., Cunha, E., Pinheiro, J. (Eds.), Forensic Anthropology and Medicine. Humana Press, Totowa, New Jersey, pp. 117-158.

Fernández, E., Arroyo-Pardo, E., 2014. Paleogenetic study of the human remains. In: Carvalho, A.F. (Ed.), Bom Santo Cave (Lisbon) and the Middle Neolithic Societies of Southern Portugal. Universidade do Algarve, Faro, pp. 133-142.

Granja, R., Alves Cardoso, F., Gonçalves, D., 2014a. Taphonomy and funerary practices. In: Carvalho, A.F. (Ed.), Bom Santo Cave (Lisbon) and the Middle Neolithic Societies of Southern Portugal. Universidade do Algarve, Faro, pp. 79-100.

Granja, R., Gonçalves, D., Alves Cardoso, F., 2014b. Osteological sample profile. In: Carvalho, A.F. (Ed.), Bom Santo Cave (Lisbon) and the Middle Neolithic Societies of Southern Portugal. Universidade do Algarve, Faro, pp. 101-120.

Jorge, V.O., 1995. Late Prehistoric funerary mounds in Northern Portugal as indicators of social complexity. In: Lillios, K.T. (Ed.), The Origins of Complex Societies in Late Prehistoric Iberia. International Monographs in Prehistory, Ann Arbor, (Archaeological Series 8), pp. 140-152.

Leitão, M., North, C.T., Norton, J., Ferreira, O.V., Zbyszewski, G., 1987. A gruta préhistórica do Lugar do Canto, Valverde (Alcanede). O Arqueólogo Português Série IV(5), 37-66.

Masset, C., 1999. Mégalithisme, société, aspects démographiques. In: Guilaine, J. (Ed.), Mégalithismes de l'Atlantique à l'Éthiopie. Éditions Errances, Paris, pp. 7-20.

Oosterbeek, L., 1987. Gruta dos Ossos. Informação Arqueológica 8, 80-81. 
Oosterbeek, L., 1993. Gruta dos Ossos, Tomar: um ossuário do Neolítico final. Boletim Cultural da Câmara Municipal de Tomar 18, 111-128.

Oosterbeek, L., Cruz, A.R., 1991. A arqueologia da morte: considerações a propósito da interpretação dos contextos sepulcrais na região de Tomar. Boletim Cultural da Câmara Municipal de Tomar 15, 269-291.

Petchey, F., 2014. Radiocarbon chronology and palaeodiets. In: Carvalho, A.F. (Ed.), Bom Santo Cave (Lisbon) and the Middle Neolithic Societies of Southern Portugal. Universidade do Algarve, Faro, pp. 143-150.

Price, T.D., 2014. Isotope proveniencing. In: Carvalho, A.F. (Ed.), Bom Santo Cave (Lisbon) and the Middle Neolithic Societies of Southern Portugal. Universidade do Algarve, Faro, pp. 151-158.

Renfrew, C., 1976. Megaliths, territories and populations. In: De Laet, S.J. (Ed.), IV Atlantic Colloquium: Acculturation and Continuity in Atlantic Europe Mainly during the Neolithic Period and the Bronze Age. De Tempel, Brugge, pp. 198-220.

Roksandic, M., 2002. Position of skeletal remains as key to understand mortuary behavior. In: Haglund, W.D., Sorg, M.H., (Eds.), Advances in Forensic Taphonomy. CRC Press, Boca Raton, pp. 95-113.

Sherratt, A., 1990. The genesis of megaliths: monumentality, ethnicity and social complexity in Neolithic north-west Europe. World Archaeol. 22, 147-167.

Vilaça, R., Cunha Ribeiro, J.P., 1987. Escavações arqueológicas na Gruta dos Alqueves (S. Martinho do Bispo, Coimbra). Trabalhos de Antropologia e Etnologia. 27, 1-24.

Zilhão, J., 1984. A Gruta da Feteira (Lourinhã). Escavação de salvamento de uma necrópole Neolítica. Trabalhos de Arqueologia 1. Instituto Português do Património Cultural, Lisboa.

Zilhão, J., 1992. Gruta do Caldeirão. O Neolítico Antigo. Trabalhos de Arqueologia 6. Instituto Português do Património Arquitectónico e Arqueológico, Lisboa. 


\section{Legends for Figure}

Fig. 1. Location (top) and excavation plan (bottom) of the Bom Santo Cave.

Fig. 2. Disturbed primary deposition of individual 1 in Room B of the Bom Santo Cave (Photo: Cidália Duarte).

Fig. 3. Frequency and dispersion of distal phalanges in Room A of the Bom Santo Cave.

Fig. 4. Frequency and dispersion of distal phalanges in Room B of the Bom Santo Cave.

Fig. 5. Spatial patterning of grave goods in Room A and Room B of the Bom Santo Cave.

Table 1. Biological profile, mtDNA haplotypes and haplogroups, isotopes and radiocarbon dating from Bom Santo Cave. ${ }^{a}$

\begin{tabular}{|c|c|c|c|c|c|c|c|c|c|}
\hline Skeleton & Room & Sex & Age & Haplotypes & Haplogroups & $\begin{array}{r}\text { Strontium } \\
\text { isotopes }\end{array}$ & $\begin{array}{l}\text { Marine } \\
\text { proteins } \\
(\%)\end{array}$ & $\begin{array}{l}\text { Aquatic } \\
\text { proteins } \\
(\%)\end{array}$ & $\begin{array}{l}\text { 14C age } \\
\text { (cal BCE) }\end{array}$ \\
\hline$\# 01$ & B & M? & Adult & $\begin{array}{l}16270 \mathrm{~T}, \\
16296 \mathrm{~T}\end{array}$ & $\mathrm{U} 5 \mathrm{~b}$ & $\begin{array}{r}0.710265: \\
\text { Local }\end{array}$ & 3 & 7 & $3455 \pm 55$ \\
\hline \#02 & B & M & Adult & $\begin{array}{l}16126 \mathrm{C}, \\
16294 \mathrm{~T}, \\
16304 \mathrm{C}\end{array}$ & $\mathrm{T} 2 \mathrm{~b}$ & $\begin{array}{r}\text { 0.711009: } \\
\text { Migrant }\end{array}$ & 6 & 6 & $3415 \pm 110$ \\
\hline \#03 & B & $\mathrm{F}$ ? & Adult & -- & -- & $\begin{array}{r}0.711296: \\
\text { Migrant }\end{array}$ & 9 & 33 & $3725 \pm 40$ \\
\hline \#04 & B & M & Adult & $\begin{array}{l}16126 \mathrm{C}, \\
16332 \mathrm{~T}\end{array}$ & $\mathrm{~J}$ & $\begin{array}{r}0.712836: \\
\text { Migrant }\end{array}$ & 11 & 39 & $3675 \pm 25$ \\
\hline
\end{tabular}




\begin{tabular}{|c|c|c|c|c|c|c|c|c|c|}
\hline$\# 05$ & B & M & Adult & -- & -- & $\begin{array}{r}\text { 0.710503: } \\
\text { Local }\end{array}$ & 10 & 23 & $3705 \pm 35$ \\
\hline \#06 & B & $\mathrm{M}$ ? & Adult & $\begin{array}{l}16195 \mathrm{C}, \\
16298 \mathrm{C}\end{array}$ & HV0 & $\begin{array}{r}0.712517: \\
\text { Migrant }\end{array}$ & 5 & 19 & $3540 \pm 75$ \\
\hline \#07 & B & M & Adult & $16221 \mathrm{~T}$ & $\mathrm{H} 10 \mathrm{e}$ & $\begin{array}{r}\text { 0.713594: } \\
\text { Migrant }\end{array}$ & 4 & 31 & $3735 \pm 45$ \\
\hline \#08 & B & I & $\begin{array}{l}\text { Probable } \\
\text { adult }\end{array}$ & -- & -- & $\begin{array}{r}0.711508: \\
\text { Migrant }\end{array}$ & 5 & 26 & $3520 \pm 85$ \\
\hline \#09 & B & I & Juvenile & $\begin{array}{l}(16189 \mathrm{C}) \\
16224 \mathrm{C}, \\
16311 \mathrm{C}\end{array}$ & K1a2a1 & $\begin{array}{r}0.710619: \\
\text { Local? }\end{array}$ & 8 & 18 & $3565 \pm 55$ \\
\hline \#10 & B & M & Adult & $\begin{array}{l}\text { 16126C, } \\
16196 \mathrm{~A}, \\
16259 \mathrm{~T}\end{array}$ & $\mathrm{~J}$ & $\begin{array}{r}0.711235: \\
\text { Migrant }\end{array}$ & 10 & 6 & $3580 \pm 45$ \\
\hline$\# 11$ & A & M & Adult & -- & -- & $\begin{array}{r}\text { 0.711783: } \\
\text { Migrant }\end{array}$ & 12 & 16 & $3540 \pm 75$ \\
\hline$\# 12$ & B & $\mathrm{F}$ ? & Adult & $\begin{array}{l}\text { 16239T, } \\
16292 \mathrm{~T}\end{array}$ & $\mathrm{H} 1$ or R8a1a3 & $\begin{array}{r}0.711702: \\
\text { Migrant }\end{array}$ & 2 & 24 & $3555 \pm 65$ \\
\hline$\# 13$ & A & F & $\begin{array}{l}\text { Probable } \\
\text { adult }\end{array}$ & -- & -- & $\begin{array}{r}0.712348: \\
\text { Migrant }\end{array}$ & 4 & 29 & $3530 \pm 80$ \\
\hline$\# 14$ & B & I & Adult & $\begin{array}{l}\text { 16221T, } \\
\text { 16256T, } \\
\text { 16270T }\end{array}$ & U5a1 & $\begin{array}{r}0.712266: \\
\text { Migrant }\end{array}$ & 6 & 42 & $3780 \pm 65$ \\
\hline "Hunter" & & & Adult & not analysed & not analysed & $\begin{array}{r}\text { not } \\
\text { analysed }\end{array}$ & 8 & 25 & $3735 \pm 45$ \\
\hline
\end{tabular}

${ }^{a}$ Adapted from Carvalho et al. (2015). 
Table 2. Completeness of each skeletal element according to Room A and Room B.

\begin{tabular}{|c|c|c|c|c|c|c|c|c|c|c|c|c|}
\hline \multirow[t]{2}{*}{ Element } & \multicolumn{4}{|c|}{ Room A } & \multicolumn{4}{|c|}{ Room B } & \multicolumn{4}{|c|}{ Total } \\
\hline & $\mathrm{n}$ & $\bar{x}$ & Md & SD & $\mathrm{n}$ & $\bar{x}$ & $\mathrm{Md}$ & SD & $\mathrm{n}$ & $\bar{x}$ & Md & SD \\
\hline Cranium & 585 & 3.89 & 4.00 & 0.52 & 828 & 3.89 & 4.00 & 0.53 & 1413 & 3.89 & 4.00 & 0.53 \\
\hline Mandible & 40 & 3.38 & 4.00 & 0.93 & 70 & 3.16 & 4.00 & 1.14 & 110 & 3.24 & 4.00 & 1.07 \\
\hline Teeth & 677 & 1.51 & 1.00 & 0.82 & 749 & 1.27 & 1.00 & 0.58 & 1426 & $1.38 * *$ & 1.00 & 0.71 \\
\hline $\begin{array}{l}\text { Vertebral } \\
\text { column }\end{array}$ & 290 & 2.82 & 3.00 & 1.17 & 623 & 2.90 & 3.00 & 1.14 & 913 & 2.87 & 3.00 & 1.15 \\
\hline Ribs & 202 & 3.35 & 4.00 & 1.05 & 341 & 3.38 & 4.00 & 0.98 & 543 & 3.37 & 4.00 & 1.00 \\
\hline Sternum & 11 & 3.45 & 4.00 & 0.93 & 35 & 3.29 & 4.00 & 0.99 & 46 & 3.33 & 4.00 & 0.97 \\
\hline Clavicle & 38 & 1.95 & 1.00 & 1.18 & 51 & 2.47 & 3.00 & 1.24 & 89 & $2.25 *$ & 2.00 & 1.24 \\
\hline Scapula & 30 & 3.87 & 4.00 & 0.35 & 67 & 3.70 & 4.00 & 0.70 & 97 & 3.75 & 4.00 & 0.61 \\
\hline Humerus & 61 & 2.34 & 2.00 & 1.17 & 57 & 3.02 & 4.00 & 1.17 & 118 & $2.67 * *$ & 2.50 & 1.21 \\
\hline Radius & 42 & 1.95 & 1.00 & 1.23 & 76 & 3.00 & 4.00 & 1.21 & 118 & $2.63 * *$ & 3.00 & 1.31 \\
\hline
\end{tabular}




\begin{tabular}{lrlllllllllll} 
Ulna & 38 & 1.79 & 2.00 & 0.81 & 65 & 2.74 & 3.00 & 1.18 & 103 & $2.39 * *$ & 2.00 & 1.15 \\
Hand & 229 & 1.57 & 1.00 & 0.90 & 923 & 1.38 & 1.00 & 0.80 & 1152 & $1.42 * *$ & 1.00 & 0.83 \\
Hip bone & 56 & 3.68 & 4.00 & 0.51 & 89 & 3.58 & 4.00 & 0.77 & 145 & 3.62 & 4.00 & 0.68 \\
Femur & 75 & 2.32 & 2.00 & 1.14 & 109 & 3.17 & 4.00 & 1.16 & 184 & $2.82 * *$ & 3.00 & 1.22 \\
Patella & 26 & 1.31 & 1.00 & 0.83 & 32 & 1.16 & 1.00 & 0.45 & 58 & 1.22 & 1.00 & 0.65 \\
Tibia & 77 & 2.18 & 2.00 & 1.14 & 96 & 3.02 & 4.00 & 1.20 & 173 & $2.65 * *$ & 2.00 & 1.24 \\
Fibula & 44 & 2.09 & 2.00 & 1.03 & 67 & 3.13 & 4.00 & 1.15 & 111 & $2.72 * *$ & 3.00 & 1.22 \\
Foot & 316 & 1.54 & 1.00 & 0.90 & 825 & 1.61 & 1.00 & 1.04 & 1141 & 1.59 & 1.00 & 1.00 \\
Total & 2837 & 2.45 & 2.00 & 1.32 & 5103 & 2.39 & 2.00 & 1.35 & 7940 & $2.42 *$ & 2.00 & 1.34 \\
\hline
\end{tabular}

Key: $\mathrm{n}=$ number of fragments; $\overline{\mathrm{X}}=$ mean; $\mathrm{Md}=$ median; $\mathrm{SD}=$ standard deviation. Statistically significant mean differences between both rooms: ${ }^{*} \mathrm{p}<0.05 ; * \mathrm{*}<0.01$. Mann-Whitney's statistics was used. Carpal and tarsal bones are included in the hand and foot categories, respectively. 

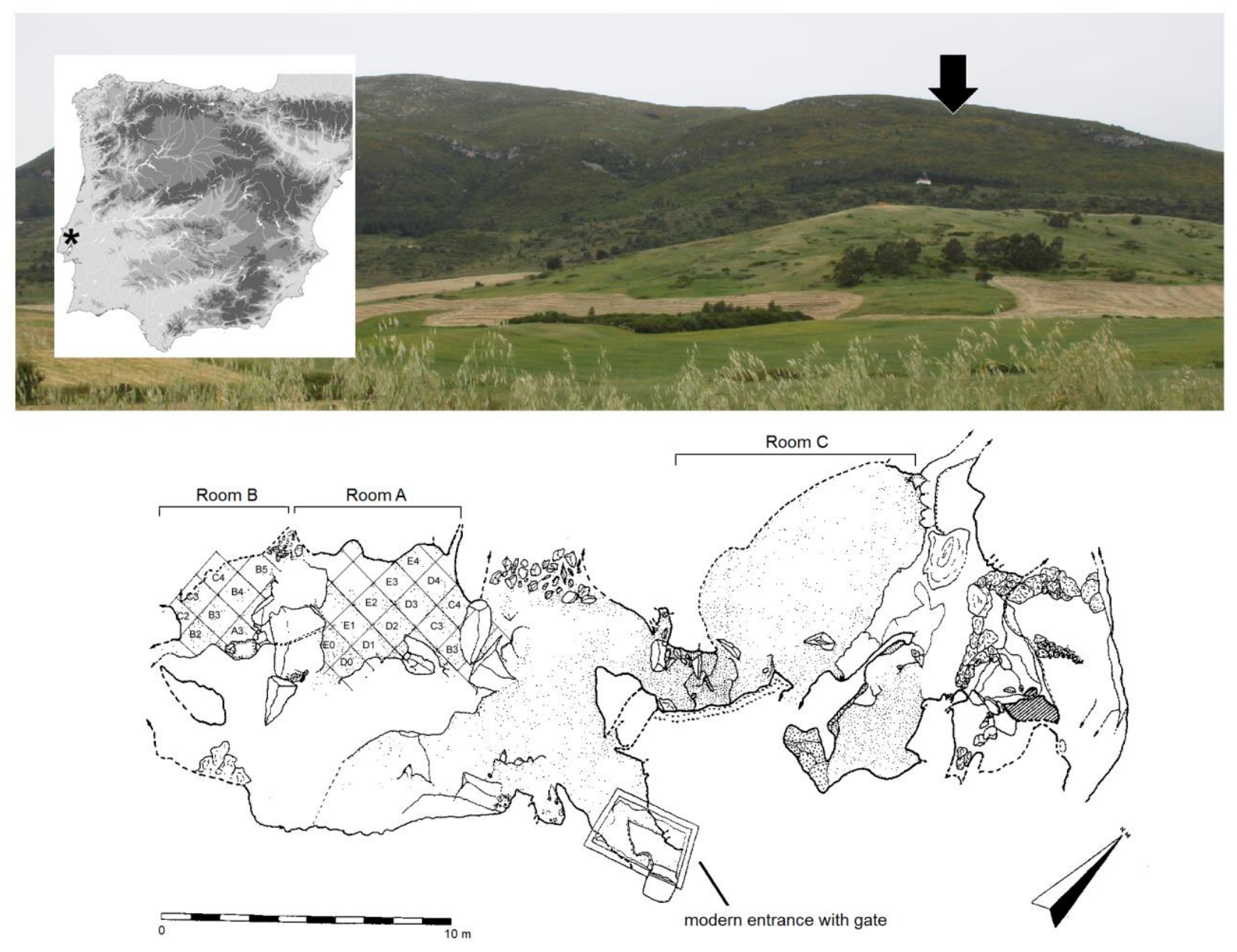

Fig. 1 


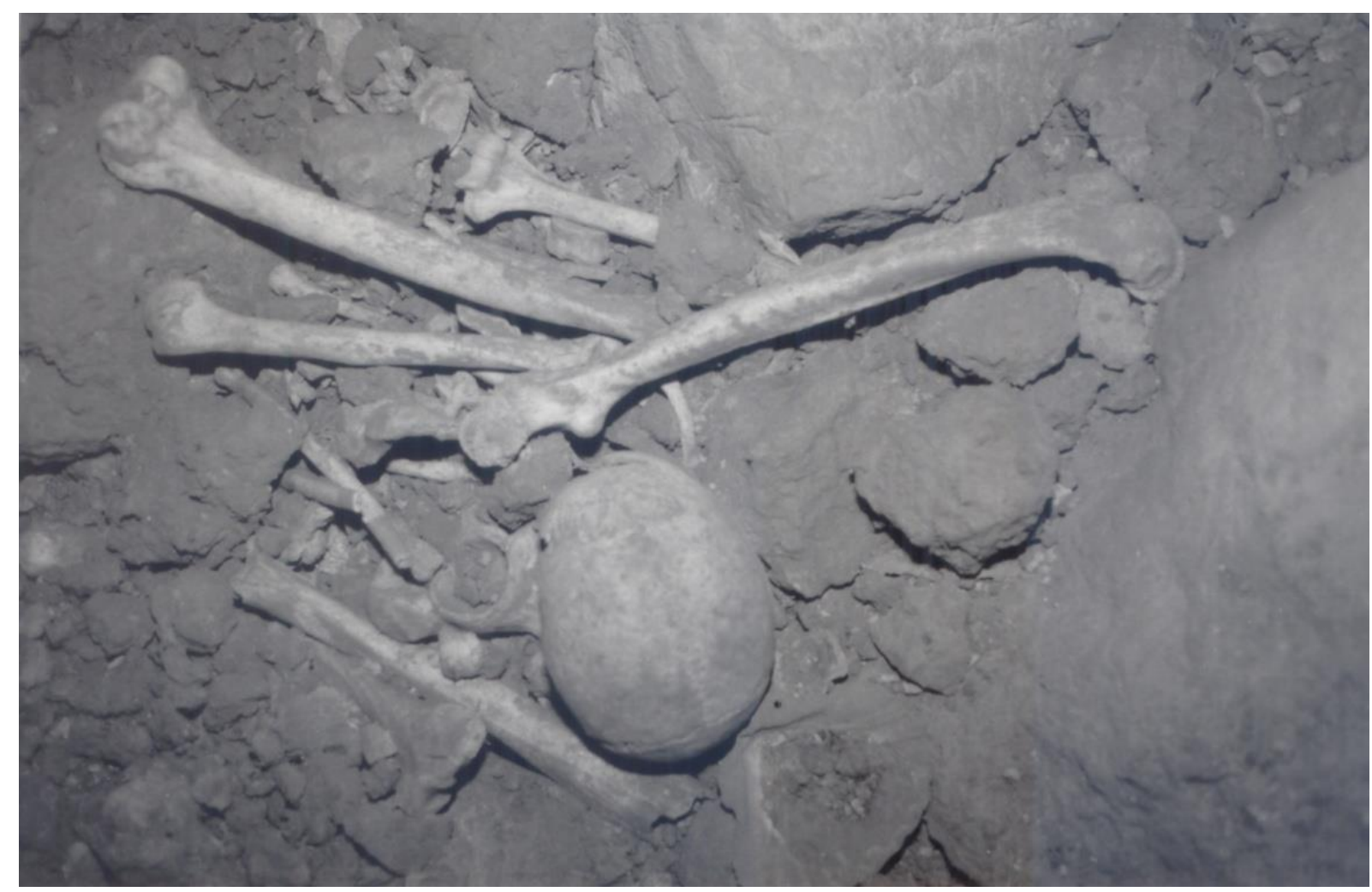

Fig. 2 


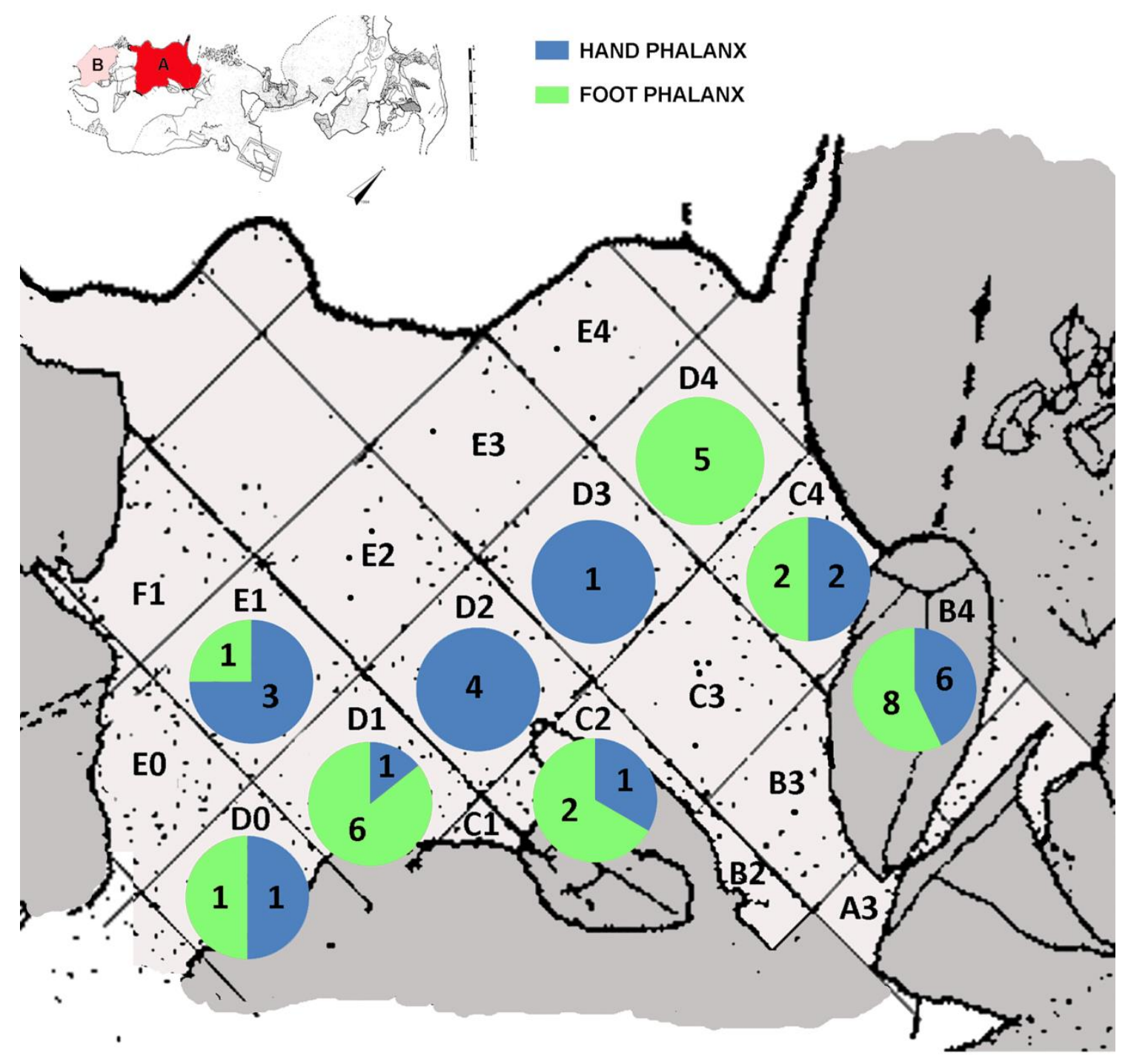

Fig. 3 


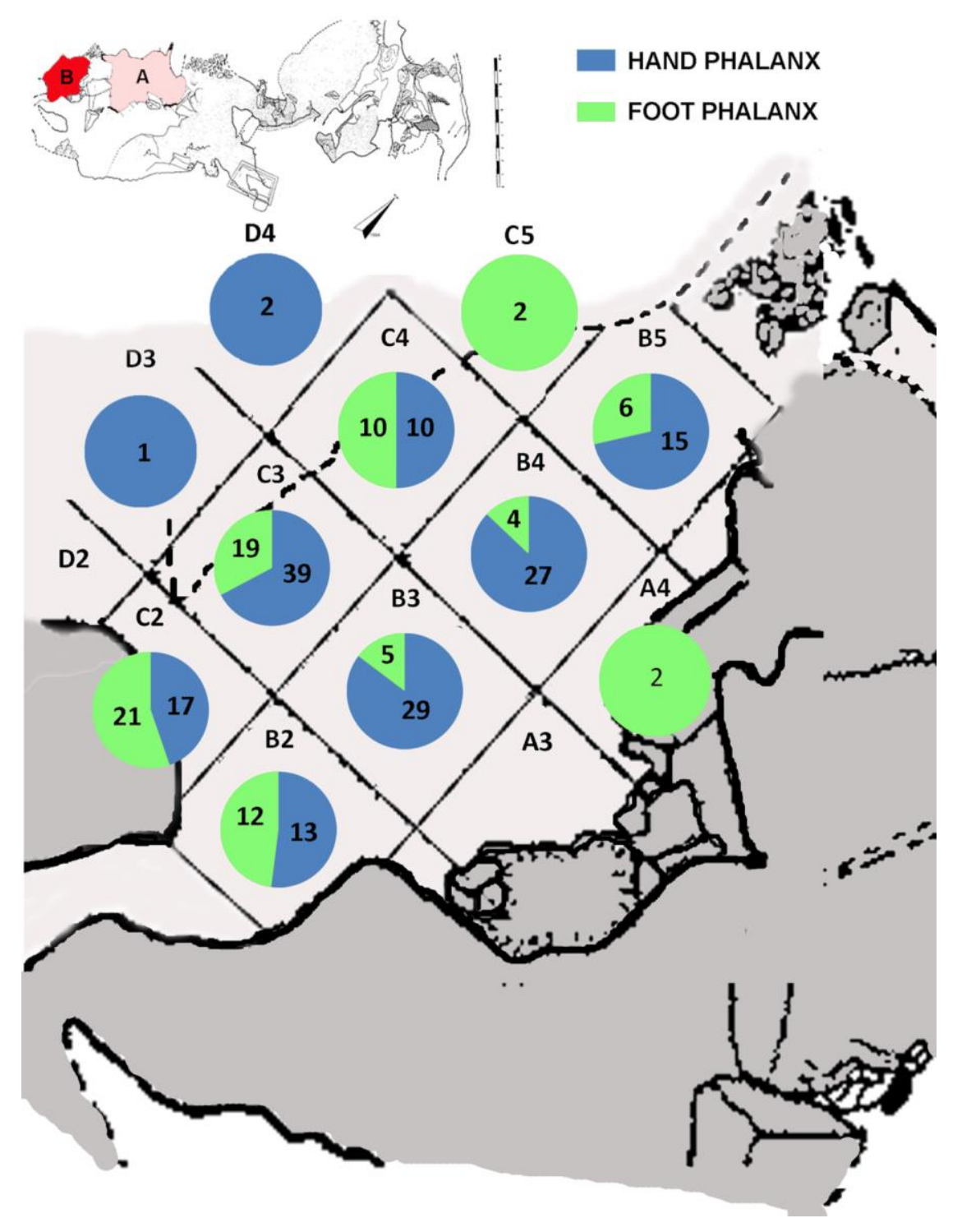

Fig. 4 

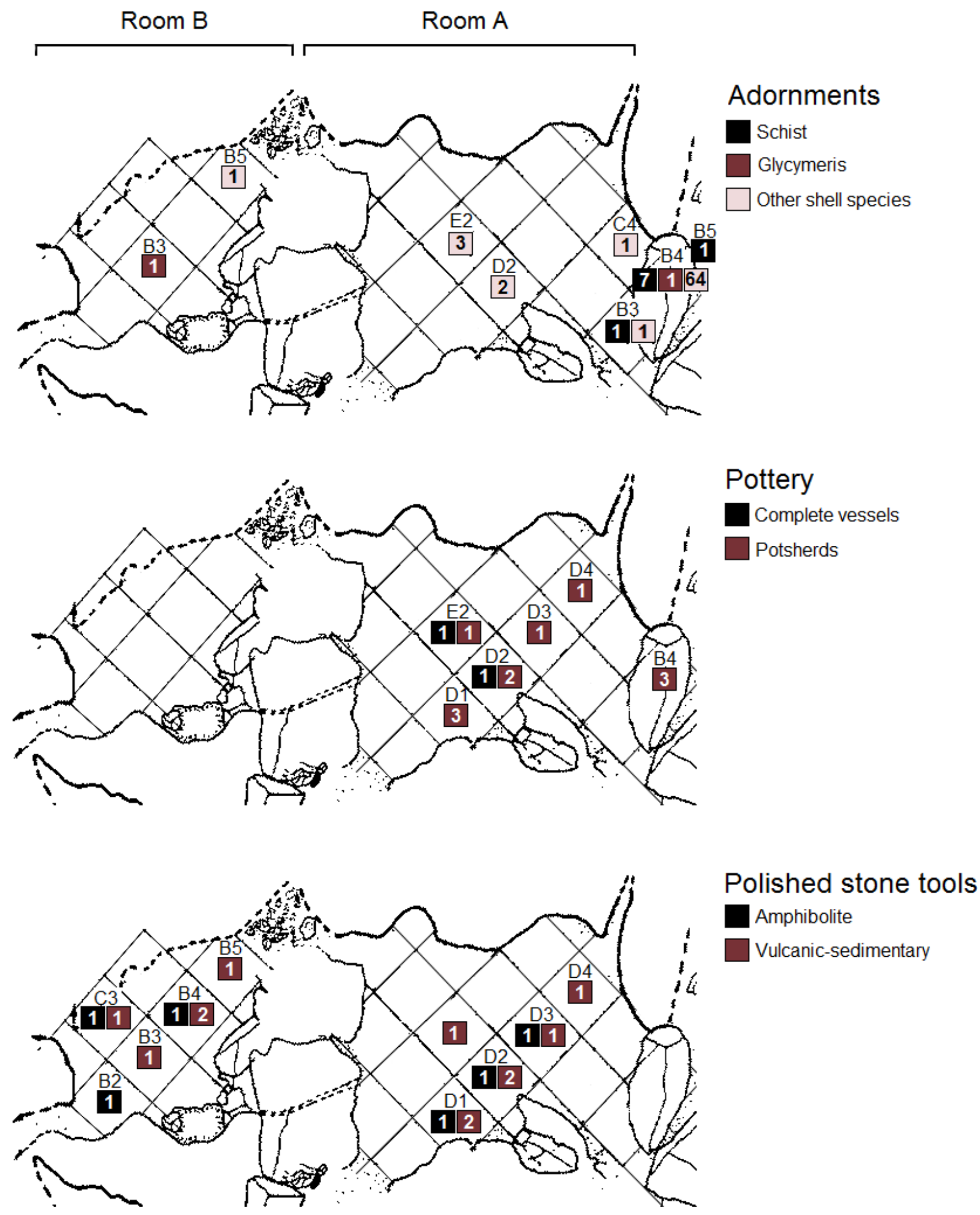

Fig. 5 
